\title{
Anxiety, depression and health locus of control in secondary school students during the COVID-19 pandemic
} Lęk, depresja, poczucie kontroli zdrowia u uczniów szkół średnich w dobie pandemii COVID-19

\author{
'Centre for Teacher Education, University of Wrocław, Wrocław, Poland \\ ${ }^{2}$ Marta Kuty-Pachecka Cognitive Behavioural Diagnosis and Therapy Practice, Wrocław, Poland \\ ${ }^{3}$ Institute of Psychology, University of Wrocław, Wrockaw, Poland \\ Correspondence: Marta Kuty-Pachecka, University of Wrocław, Cybulskiego 30, 50-205 Wrocław, Poland, e-mail: marta.kuty-pachecka@uwr.edu.pl
}

${ }^{1}$ Centrum Edukacji Nauczycielskiej, Uniwersytet Wrocławski, Wrocław, Polska

${ }^{2}$ Gabinet Diagnozy i Terapii Poznawczo-Behawioralnej Marta Kuty-Pachecka, Wrocław, Polska

${ }^{3}$ Instytut Psychologii, Uniwersytet Wrocławski, Wrocław, Polska

Adres do korespondencji: Dr n. hum. Marta Kuty-Pachecka, UniwersytetWrocławski, ul. cybulskiego 30, 50-205 Wrocław, e-mail: marta.kuty-pachecka@uwr.edu.pl

\begin{abstract}
Introduction: During the COVID-19 pandemic young people are experiencing anxiety and tension associated with an unusual, unclear and unpredictable situation. Deterioration of the economic situation resulting from the pandemic, social distancing, school closure and a real threat to health and life are strong anxiety-inducing factors. Aim: The aim of the study was to determine the level of depression among adolescents and which of the factors related to the pandemic (health-related anxieties and restrictions) were the most difficult for them. We also wanted to verify the differences in depression and anxiety in girls and boys, and the relationship between anxiety, depression and health locus of control in adolescents. Method: The study covered 296 people from 17 to 19 years old. The research was carried out using the Kutcher Adolescent Depression Scale (KADS), the State-Trait Anxiety Inventory (STAI) and the Multidimensional Health Locus of Control (MHLC). Results: The results of the study indicate that the youth experience elevated levels of depression during the COVID-19 pandemic. 75\% of the participants experienced depression symptoms. The severity of the perceived state of anxiety and depressive symptoms was significantly higher among adolescent girls than among boys. In addition, individuals who reported anxious thoughts about the possibility of someone in their family contracting COVID-19 experienced significantly higher levels of depressive symptoms than those who did not. Additionally, the internal health locus of control negatively correlated with both anxiety as a state and depression, while the external (chance-related) health locus of control correlated positively with depression and anxiety.
\end{abstract}

Keywords: depression, anxiety, health locus of control

Wstęp: W dobie pandemii COVID-19 młode osoby doświadczają lęku i napięcia związanego z nietypową, niejasną i nieprzewidywalną sytuacją. Silnymi bodźcami lękotwórczymi są dystans społeczny, zamknięcie szkół oraz realne zagrożenie zdrowia i życia, przekładające się na duże obciążenie psychiczne u młodych osób. Cel: Prezentowane badania miały na celu określenie poziomu depresji wśród młodzieży oraz ustalenie, które czynniki związane z pandemią (obawy o zdrowie, ograniczenia) okazały się dla uczniów najtrudniejsze. Celem była także weryfikacja różnic w zakresie nasilenia depresji i lęku u dziewcząt i chłopców oraz zależności między lękiem i depresją a umiejscowieniem poczucia kontroli zdrowia u adolescentów. Metoda: Badaniami objęto 296 osób w wieku 17-19 lat. Do realizacji badań posłużyły: Skala Depresji Kutchera dla Młodzieży (Kutcher Adolescent Depression Scale, KADS), Inwentarz Stanu i Cechy Lęku (State-Trait Anxiety Inventory, STAI) oraz Wielowymiarowa Skala Umiejscowienia Kontroli Zdrowia (Multidimensional Health Locus of Control, MHLC). Wyniki: Nasilenie objawów depresji w dobie pandemii koronawirusa wynosiło wśród młodzieży 75\%. Nasilenie stanu lęku i objawów depresyjnych było istotnie większe wśród dziewcząt niż wśród chłopców. Ponadto osoby, które zgłosiły niepokojące myśli o możliwości zarażenia się SARS-CoV-2 przez kogoś z rodziny, doświadczały znacznie silniejszych objawów depresyjnych niż osoby, które nie miały podobnych obaw. Wewnętrzne umiejscowienie kontroli zdrowia korelowało ujemnie zarówno z lękiem jako stanem, jak i z depresją. Z kolei zewnętrzne umiejscowienie kontroli zdrowia związane z przypadkiem korelowało dodatnio z depresją i lękiem. 


\section{INTRODUCTION}

$\mathrm{T}$ he COVID-19 pandemic is a crisis situation, in which young people experience strong fear of becoming infected or infecting other people, particularly considering the fact that the COVID-19 transmission model is not clear, as was the case at the beginning of the pandemic. Symptoms typical for other diseases (the common cold or influenza) can also induce fear since they can be attributed to COVID-19 and bring about strong anxiety (International Federation of Red Cross and Red Crescent Societies, 2020). The atypical situation involving school closure, lack of contact with peers and social distancing can also be a potential source of anxiety for adolescents. Quarantine at home, lack of outdoor activities and high school workload can cause a higher emotional and mental burden (Ghosh et al., 2020). The COVID-19 pandemic, during which chance and external factors affect the lives of individuals, can increase anxiety and depression among the Polish youth.

The aim of the study was to determine if there are any differences among young people in terms of depression and anxiety with regard to the experiences associated with the pandemic. Differences concerning the symptoms of depression and anxiety between the individuals who reported anxious thoughts about the possibility of becoming infected with SARS-CoV-2 (regarding themselves or the family members) and those who did not report such concerns were analysed. It was assessed which of the pandemic-related restrictions turned out to be the most difficult to the respondents. In addition, the aim of the study was to verify the differences in depression and anxiety among girls and boys and to analyse the relationship between anxiety and depression and health locus of control in adolescents during the COVID-19 pandemic.

\section{DEPRESSION AND ANXIETY IN ADOLESCENTS}

Depression is a common mental disturbance, which primarily manifests with a decrease in mood, energy and activity. Depression often makes normal functioning impossible and is associated with a compromised quality of life (Rybakowski et al., 2010). In terms of key symptoms, the clinical presentation of depression in childhood and adolescence and in adulthood is considered to be the same, which is reflected in a lack of differentiation between them in diagnostic classifications (Trzęsowska-Greszta et al., 2014). Adolescent depression is not a nosological entity; there are also data to support the argument that adolescent depression is a disturbance of functioning that does not extend beyond a developmental norm, particularly if it occurs at an early stage of puberty. As such, it can be considered as an adaptive functional deterioration caused by a number of significant biological, cognitive, social and family system changes

\section{WPROWADZENIE}

$\mathrm{P}$ andemia COVID-19 to sytuacja kryzysowa, w której młodzi ludzie doświadczają silnego lęku przed zakażeniem się lub zakażeniem innych osób, szczególnie że model transmisji COVID-19 nie jest jasny, jak było to w początkowym okresie pandemii. Czynnikiem lękorodnym są także objawy typowe dla innych chorób (przeziębienia czy grypy), które mogą zostać przypisane COVID-19 i budzić silny niepokój (International Federation of Red Cross and Red Crescent Societies, 2020). Potencjalnym źródłem niepokoju adolescentów jest również nietypowa sytuacja związana z zamknięciem szkół, brakiem kontaktu z rówieśnikami i dystansem społecznym. Kwarantanna w domu, brak aktywności na świeżym powietrzu, duże obciążenie nauką mogą powodować większe obciążenie emocjonalne i psychiczne (Ghosh et al., 2020). Pandemia COVID-19, podczas której przypadek i zewnętrze czynniki wpływają na funkcjonowanie jednostek, może nasilać lęk i depresję wśród polskiej młodzieży.

Celem przeprowadzonych badań było określenie, czy wśród młodzieży istnieją różnice w zakresie depresji i lęku w zależności od przeżyć związanych z pandemią. Przeanalizowano różnice dotyczące objawów depresji i lęku u osób, które zgłosiły niepokojące myśli o możliwości zarażenia się SARS-CoV-2 (odnoszące się do samego siebie i do członków rodziny), w porównaniu z osobami niezgłaszającymi podobnych obaw. Oceniono, które ograniczenia w czasie pandemii okazały się dla respondentów najtrudniejsze. Ponadto celem badania była weryfikacja różnic w zakresie depresji i lęku u dziewcząt i chłopców oraz analiza zależności między lękiem i depresją a umiejscowieniem poczucia kontroli zdrowia u adolescentów $\mathrm{w}$ trakcie pandemii COVID-19.

\section{DEPRESJA I LĘK U ADOLESCENTÓW}

Depresja to powszechnie występujące zaburzenie psychiczne, którego głównymi symptomami są obniżenie nastroju oraz spadek energii i aktywności. Często uniemożliwia normalne funkcjonowanie i wiąże się z pogorszeniem jakości życia (Rybakowski et al., 2010). Pod względem kluczowych symptomów obraz kliniczny depresji wieku rozwojowego i depresji u dorosłych uznawany jest za tożsamy, co znajduje odzwierciedlenie w braku rozróżnienia kryteriów w klasyfikacjach diagnostycznych (Trzęsowska-Greszta et al., 2014). Mimo że depresja młodzieńcza nie jest jednostką nozologiczną, istnieją również dane wspierające tezę, że stanowi ona zakłócenie funkcjonowania niewykraczające poza normę rozwojową, szczególnie jeśli pojawia się na wczesnym etapie dojrzewania. Można ją wówczas rozpatrywać jako adaptacyjne pogorszenie funkcjonowania, uwarunkowane szeregiem istotnych zmian biologicznych, poznawczych, społecznych i zmian w systemie rodzinnym adolescenta (Bomba i Orwid, 2004). Według klasyfikacji Światowej Organizacji Zdrowia (ICD-10) epizod depresyjny można zdiagnozować, jeśli spełnione są 
According to the World Health Organization (ICD-10), a depressive episode may be diagnosed if a minimum of two out of three primary criteria are met over a period of at least two weeks and a minimum of two additional criteria are present. The first of the primary criteria for a depressive episode is a decreased mood to a level that is clearly abnormal for a given person; such a mood persists for most of the day, is present almost every day and is hardly affected by external events (it is assumed that in adolescents, the mood can be irritable rather than decreased). The second primary criterion is loss of interest and anhedonia. The third criterion involves decreased energy levels or increased fatigability leading to reduced activity. Additional criteria include compromised concentration, low self-esteem and self-confidence, sense of guilt, pessimistic outlook on the future, suicidal thoughts and actions, sleep disturbances and decreased appetite (Pużyński and Wciórka, 2007). Apart from the typical symptoms mentioned above, depression also involves decreased cognitive function, usually in the form of psychomotor retardation, and compromised executive functions and working memory (Jarema et al., 2014).

Anxiety is an emotional state associated with the perception of danger present in the surrounding environment or inside the body of an individual, which is accompanied by many symptoms of agitation (Flack and Laird, 1998). In the literature on the subject, a distinction is made between anxiety as a state and anxiety as a trait (Cattell, 1966). Short-term anxiety is experienced by a vast majority of the population, including children and adolescents. However, anxiety can also be understood as a permanent trait of personality, which is reflected in frequent perception of various situations as threatening and dangerous. It is anxiety as a trait that is the traditional meaning used in psychopathology and included in the current classifications (DSM-5, ICD-10). However, the psychopathological dimension of anxiety is determined by the presence of other symptoms (Pużyński and Wciórka, 2007).

In developed countries, depression is currently one of the most common diseases with a severely negative impact on everyday functioning, which is also widespread among adolescents. Depression has an adverse influence on developmental processes, makes it difficult or impossible to pursue activities typical of the period of puberty, and, if untreated, can lead to suicidal thoughts, auto-aggression, suicide attempts and suicides. Research indicates that an episode of major depressive disorder (MDD) can occur in 4-8\% of adolescents during puberty and as many as $20 \%$ of individuals aged approximately 18 years (Brent and Pan, 2011). In a study including 125 state school pupils, $18 \%$ of the participants were found to have depression, $15 \%$ an elevated level of anxiety and nearly $6 \%$ met the criteria of both disorders at the same time (Bansal et al., 2009). The authors of the study report a prevalence of 3-9\% for depression in adolescence and $20 \%$ for depression towards the end of adolescence. Other sources include data indicating a prevalence minimum dwa z trzech głównych kryteriów - w okresie co najmniej dwóch tygodni - i minimum dwa kryteria dodatkowe. Pierwszym z głównych kryteriów jest obniżenie nastroju w stopniu wyraźnie nieprawidłowym dla danej osoby, utrzymujące się przez większość dnia i niemal każdego dnia, w niewielkim stopniu podlegające wpływowi wydarzeń zewnętrznych (zakłada się, iż u adolescentów może występować nastrój nie obniżony, ale drażliwy). Drugie z głównych kryteriów to utrata zainteresowań i anhedonia, trzecie zaś - zmniejszona energia lub zwiększona męczliwość, prowadzące do spadku aktywności. Kryteria dodatkowe obejmują osłabienie koncentracji, niską samoocenę i małą wiarę w siebie, poczucie winy, pesymistyczne widzenie przyszłości, myśli i czyny samobójcze, zaburzenia snu oraz zmniejszony apetyt (Pużyński i Wciórka, 2007). Oprócz wymienionych wyżej typowych objawów w depresji występują również obniżenie funkcji poznawczych, najczęściej w postaci spowolnienia psychoruchowego, oraz zaburzenia funkcji wykonawczych i pamięci operacyjnej (Jarema et al., 2014).

Lęk to stan emocjonalny, który wiąże się z postrzeganiem niebezpieczeństwa obecnego w środowisku lub wewnątrz organizmu jednostki i któremu towarzyszy wiele objawów pobudzenia (Flack i Laird, 1998). W literaturze przedmiotu pojawia się rozróżnienie na lęk jako stan i lęk jako cechę (Cattell, 1966). Krótkotrwałych stanów lęku doświadcza zdecydowana większość populacji, także dzieci i młodzież. $\mathrm{Z}$ kolei lęk rozpatrywany jako trwała część osobowości jest stałą cechą, która wyraża się w częstym przeżywaniu najróżniejszych sytuacji jako zagrażających, niebezpiecznych. Właśnie tak - jako cechę - lęk pojmuje się tradycyjnie w psychopatologii i uwzględnia w obowiązujących klasyfikacjach (DSM-5, ICD-10). Psychopatologiczny wymiar lęku jest jednak określony występowaniem innych objawów (Pużyński i Wciórka, 2007).

W krajach rozwiniętych depresja to obecnie jedna $\mathrm{z}$ najczęstszych chorób, bardzo poważnie utrudniająca codzienne funkcjonowanie i szeroko rozpowszechniona również wśród adolescentów. Wpływa niekorzystnie na procesy rozwojowe, utrudnia albo uniemożliwia realizację zadań charakterystycznych dla okresu dojrzewania, a nieleczona może prowadzić do myśli samobójczych, autoagresji, prób samobójczych i samobójstw. Badania wskazują, że duży epizod depresji (major depressive disorder, MDD) może występować u 4-8\% młodzieży w okresie dojrzewania i aż $20 \%$ osób w wieku około 18 lat (Brent i Pan, 2011). W badaniach z udziałem 125 uczniów szkół publicznych depresję stwierdzono u $18 \%$ uczestników, podwyższony poziom lęku - u 15\%, a prawie 6\% spełniało kryteria obu zaburzeń równocześnie (Bansal et al., 2009). Autorzy badania podają rozpowszechnienie depresji na poziomie 3-9\% wśród ludzi w wieku nastoletnim i prawie $20 \%$ wśród wychodzących z okresu adolescencji. W innych źródłach można znaleźć dane mówiące o rozpowszechnieniu depresji (w tym MDD) u adolescentów na poziomie $2-15 \%$ i o obniżaniu się wieku wystąpienia pierwszego epizodu depresyjnego (za: Kołodziejek, 2008). 
of depression (including MDD) in adolescents at $2-15 \%$ and an ever-decreasing age of the first depressive episode (as reported in: Kołodziejek, 2008).

A study on depression and anxiety conducted on a group of young athletes aged 14-18 years using the Hospital Anxiety and Depression Scale (HADS) indicates that in terms of anxiety $6.7 \%$ of the participants had subclinical scores and $3.4 \%$ clinically significant ones. On the depression subscale, the scores of $9.5 \%$ of the adolescents were subclinical, while those of $3.7 \%$ were clinically significant (Weber et al., 2018).

Polish research demonstrated that in childhood, depressive symptoms are more common in boys and in adolescence, they are more common in girls. A study including 1,933 pupils (gender proportions: female: $55 \%$, male: $45 \%$ ), which used Beck Depression Inventory, indicates that $33.6 \%$ of girls and $22.7 \%$ of boys presented with depressive symptoms (Modrzejewska and Bomba, 2010). The prevalence of depressive disorders among Polish adolescents was also investigated by Dymowska and Nowicka-Sauer (2015). They studied a group of 18-year-old final year secondary school pupils (68 individuals: 45 girls and 23 boys). The authors used the Primary Care Evaluation of Mental Disorders (PRIME-MD PHQ) test, which is used for preliminary assessment of the most common mental disorders (Dymowska and Nowicka-Sauer, 2015). The results of the study are the following: depressive disorders: $25.7 \%$ of the participants, depressive episode: 5 individuals, suicidal thoughts: $14.3 \%$ of the group (Dymowska and Nowicka-Sauer, 2015).

During the pandemic, as is the case with disasters, there is an increased risk of depression and anxiety (Chen et al., 2020; Douglas et al., 2009; Guessoum et al., 2020). In a study conducted during the COVID-19 pandemic among 8,079 Chinese adolescents aged $12-18$ years, there was a high prevalence of symptoms of depression (43\%) and anxiety (37\%), and depression and anxiety co-occurred in $31 \%$ of the subjects (Zhou et al., 2020). In girls, the rate of symptoms was significantly higher than in boys. Another study carried out among adolescents during the COVID-19 pandemic indicates that 112 individuals $(11.78 \%)$ had a diagnosis of depression and 196 (18.92\%) had a high level of anxiety (Chen et al., 2020). In a study by Xie et al. (2020), which included 2,330 pupils, $22.6 \%$ of the subjects reported symptoms of depression and $18.9 \%$ symptoms of anxiety.

\section{HEALTH LOCUS OF CONTROL}

One of the key factors for mental endurance is locus of control (LOC) (Argyle, 2002). The concept of LOC was developed by Julian B. Rotter, who believed that behaviour is a function of expectations, reinforcement and psychological situation in which, depending on the perceived source of reinforcement, the subject develops an internal or external locus of control (Sęk, 2005). Inner-directedness, in contrast to outer-directedness, is reflected in a stronger tenden-
Badania na temat depresji i lęku przeprowadzone w grupie młodych sportowców w wieku 14-18 lat za pomocą Szpitalnej Skali Lęku i Depresji (Hospital Anxiety and Depression Scale, HADS) wskazują, że w podskali lęku 6,7\% uczestników uzyskało wyniki subkliniczne, a 3,4\% - wartości istotne klinicznie. W podskali depresji 9,5\% adolescentów uzyskało subkliniczne wartości punktowe, natomiast 3,7\% - kliniczne (Weber et al., 2018).

Polskie badania wykazały, że w okresie dzieciństwa objawy depresji częściej występują u chłopców, a od wieku dojrzewania - u dziewcząt. Wyniki badań z udziałem 1933 uczniów (proporcje płci: żeńska - 55\%, męska - 45\%), których stan oceniano przy użyciu Skali Depresji Becka, wskazują, że objawy depresyjne prezentowało 33,6\% dziewcząt i 22,7\% chłopców (Modrzejewska i Bomba, 2010). Problem rozpowszechnienia zaburzeń depresyjnych wśród polskiej młodzieży podjęły w swoich badaniach również Dymowska i Nowicka-Sauer (2015). Przebadały one grupę 18-letnich uczniów klas maturalnych liceów ogólnokształcących (68 osób: 45 dziewcząt i 23 chłopców). Autorki wykorzystały test Primary Care Evaluation of Mental Disorders (PRIME-MD PHQ), służący do wstępnej oceny najpowszechniejszych zaburzeń psychicznych (Dymowska i Nowicka-Sauer, 2015). Wyniki badań przedstawiają się następująco: rozpowszechnienie zaburzeń depresyjnych - 25,7\% uczestników, wystąpienie epizodu depresji - 5 osób, obecność myśli samobójczych - 14,3\% grupy (Dymowska i Nowicka-Sauer, 2015).

W czasie pandemii, tak jak w przypadku katastrof, istnieje zwiększone ryzyko depresji i lęku (Chen et al., 2020; Douglas et al., 2009; Guessoum et al., 2020). W badaniu przeprowadzonym w trakcie pandemii COVID-19 wśród 8079 chińskich nastolatków (wiek: 12-18 lat) wykazano duże rozpowszechnienie objawów depresji (43\%) i lęku (37\%), a także współwystępowanie depresji i lęku u 31\% uczestników (Zhou et al., 2020). U dziewcząt wskaźnik objawów był istotnie wyższy niż wśród chłopców. Inne badania przeprowadzone wśród adolescentów w okresie pandemii COVID-19 wskazują, że 112 (11,78\%) osób miało zdiagnozowaną depresję, a u 196 (18,92\%) zaobserwowano wysoki wskaźnik lęku (Chen et al., 2020). Z kolei w badaniach Xie i wsp. (2020), dotyczących grupy 2330 uczniów, 22,6\% uczestników zgłosiło objawy depresji, a 18,9\% - lęku.

\section{POCZUCIE KONTROLI ZDROWIA}

Jednym z czynników kluczowych dla odporności psychicznej jest poczucie umiejscowienia kontroli (locus of control, LOC) (Argyle, 2002). Twórca pojęcia LOC - Julian B. Rotter uważał, że zachowanie to funkcja oczekiwań, wzmocnienia i sytuacji psychologicznej, w której zależnie od postrzeganego źródła wzmocnienia podmiot wykształca wewnętrzne albo zewnętrzne poczucie umiejscowienia kontroli (Sęk, 2005). Wewnątrzsterowność w porównaniu z zewnątrzsterownością wyraża się w silniejszym dążeniu do kontrolowania własnego otoczenia, większej odpowiedzialności 
actions, search for information, learn and make independent decisions (Ogińska-Bulik and Juczyński, 2010).

First attempts at empirical adaptation of the concept of locus of control to the health/disease domain were made by Kirscht et al. (Dabbs and Kirscht, 1971, Kirscht, 1972; as reported in: Wallston and Wallston, 1982). This idea was extensively studied and popularised as health locus of control by Barbara and Kenneth Wallston, the authors of the Multidimensional Health Locus of Control Scale (MHLC) (Wallston, 1991; Wallston and Wallston, 1982). The researchers made the assumption that internal health locus of control (HLC) supports taking more responsibility for one's health, and, consequently, preserving it. External health locus of control was divided into powerful others HLC and chance HLC, both of which are less favourable for health in terms of initiating new health-promoting behaviour, except for unusual events of acute or chronic diseases, in which a predominant conviction of the influence of others can be beneficial to the subject (Ogińska-Bulik and Juczyński, 2010).

A study by Helmer et al. (2012) conducted on German students confirms that there is an association between internal health locus of control and a stronger tendency to maintain healthy habits (healthy eating or physical activity) and an association between external locus of control (a conviction that the quality of one's health is based on chance) and a stronger tendency for harmful behaviours (smoking, lower physical activity, poorer eating habits).

It is also worth emphasising the fact that an extreme internal health locus of control can be associated with self-accusation in the case of failure (Sęk, 2005).

The influence of health locus of control is most relevant to unclear, ambiguous situations (Juczyński, 1999). The authors of MHLC emphasise that the construct directly derived from Rotter's social learning theory has a significant impact on an individual's behaviour only if they consider health preservation to be important. For this reason, in order to be able to treat health locus of control as a predictor of health-promoting behaviour, one needs to measure the value assigned to health concurrently (Wallston, 1991). Research on children, adolescents and adults performed using MHLC shows that during young age the conviction that others have an impact on one's health decreases and internal sense of control increases; however, in adulthood, there is the opposite tendency: with age, internal locus of control decreases and the impact of others and chance increases (Ogińska-Bulik and Juczyński, 2010). There are no distinct, statistically significant differences between the sexes, although adult men have a tendency for a greater internal locus of control (Ogińska-Bulik and Juczyński, 2010).

\section{LOCUS OF CONTROL AND DEPRESSION AND ANXIETY}

According to Albert Ellis (2005), depressive disorders have a destructive effect on an individual, since they cause anxiety, za swoje działania oraz tendencji do szukania informacji, uczenia się i bardziej samodzielnego podejmowania decyzji (Ogińska-Bulik i Juczyński, 2010).

Pierwsze próby empirycznego zaadaptowania umiejscowienia kontroli do obszaru zdrowia/choroby podjęli Kirscht i wsp. (Dabbs i Kirscht, 1971, Kirscht, 1972; za: Wallston i Wallston, 1982). Odniesienie to szeroko zbadali i upowszechnili jako umiejscowienie kontroli zdrowia Barbara i Kenneth Wallstonowie, autorzy Wielowymiarowej Skali Umiejscowienia Kontroli (Multidimensional Health Locus of Control, MHLC) (Wallston, 1991; Wallston i Wallston, 1982). Badacze przyjęli założenie, że wewnętrzne umiejscowienie kontroli zdrowia (internal health locus of control, HLC) sprzyja większej odpowiedzialności za własne zdrowie, a w rezultacie - jego utrzymaniu. Zewnętrzne umiejscowienie kontroli zdrowia podzielono zaś na to związane z wpływem innych (powerful others HLC) i to będące wynikiem przypadku (chance HLC) - obydwa mniej korzystne dla zdrowia w odniesieniu do inicjowania nowych zachowań zdrowotnych, poza wyjątkowymi sytuacjami chorób ostrych czy przewlekłych, gdy dominujące przekonanie o wpływie innych może służyć podmiotowi (Ogińska-Bulik i Juczyński, 2010).

Badania Helmer i wsp. (2012) przeprowadzone na niemieckich studentach potwierdzają, że istnieje związek między wewnętrznym umiejscowieniem kontroli zdrowia a silniejszą tendencją do utrzymywania zdrowych nawyków (zdrowe odżywianie czy aktywność fizyczna) oraz związek między zewnętrznym umiejscowieniem kontroli - przekonaniem, iż o stanie zdrowia decyduje przypadek - a silniejszą tendencją do zachowań szkodzących zdrowiu (palenie, niższa aktywność fizyczna, mniejsza dbałość o zdrowe odżywianie).

Warto także zaznaczyć, że jeśli poczucie wewnętrznego umiejscowienia kontroli osiąga skrajne nasilenie, może się wiązać np. z samooskarżaniem w razie niepowodzeń (Sęk, 2005).

Wpływ poczucia kontroli zdrowia na zachowanie odnosi się głównie do sytuacji niejasnych, wieloznacznych (Juczyński, 1999). Autorzy MHLC podkreślają, że konstrukt wywodzący się bezpośrednio z teorii społecznego uczenia się Rottera ma istotny wpływ na zachowanie jednostki tylko w sytuacji, w której przypisuje ona utrzymaniu zdrowia znaczenie. Dlatego aby móc traktować poczucie kontroli zdrowia jako predyktor zachowań prozdrowotnych, należy równocześnie dokonywać pomiaru wartości przypisywanych zdrowiu (Wallston, 1991).

Badania dzieci, młodzieży i dorosłych prowadzone przy użyciu MHLC pokazują, że w okresie rozwojowym spada poczucie wpływu innych na zdrowie jednostki, a rośnie kontrola wewnętrzna, natomiast w dorosłości zarysowuje się tendencja przeciwna: wraz z wiekiem spada poczucie kontroli wewnętrznej i rośnie waga wpływu innych oraz przypadku (Ogińska-Bulik i Juczyński, 2010). Brakuje tu wyraźnych, istotnych statystycznie różnic między płciami, chociaż dorośli mężczyźni mają tendencję do przypisywania 
uncertainty, sense of guilt, passivity and a catastrophic attitude towards future events. Ellis (2005) states that one of irrational convictions is the belief that happiness and unhappiness of an individual depend on other people and on the environment.

Cairns et al. (1990) indicated that there is a distinct trend towards a reduction of external locus of control among secondary school pupils. In their longitudinal study, Chubb et al. (1997) observed that locus of control in children becomes more internal with age. No significant differences were found between the sexes in terms of locus of control. According to Fiszer and Sobów (2013), this is due to the fact that adolescents remain dependent on others (teachers, parents) and, as a result, do not have a sense of complete control over what happens to them. The same authors report that gender turned out to be a factor that distinctly set apart the results achieved by medical university students aged between 20 and 25 years: men declared internal control significantly more frequently, while women scored higher results on external locus of control. No association between gender and the level of depression was found. However, Fiszer and Sobów emphasise a significant correlation between depression and internal locus of control in the group of students. In a study by Dudek (2014), gender made a significant difference for Beck's scores, and the problem of depression affected girls to a larger extent than boys.

Gomez (1998) stresses that there are more cases of depression among individuals with an external locus of control. In her study on fifth-grade primary school pupils in the Polish Western Pomeranian region, SpotonWydra (2018) demonstrated a relationship between locus of control and the severity of depressive symptoms: outerdirected children experienced depressive disorders more frequently than inner-directed ones. A study by Khumalo and Plattner (2019) on students in Botswana also proved that adolescents with an internal locus of control are less susceptible to depression. The researchers emphasise that locus of control is one of the variables that play an important role in depression.

In their classic study, Hoehn-Saric and McLeod (1985) demonstrated on a clinical sample that patients with external locus of control were more depressed, had a higher level of anxiety as a state, displayed more indecisiveness and fatigue, and had stronger symptoms of agoraphobia than those with internal locus of control. Dilmaç et al. (2009) conducted a study on a group of students aged 17-26 years and confirmed a positive correlation between external locus of control and the level of anxiety. Song and Li (2019) found that locus of control and intolerance of uncertainty in older people are strongly associated with anxiety as a trait. Mediational analysis demonstrated that intolerance of uncertainty partly mediated the effect of locus of control on anxiety as a trait. In a study on locus of control, depression and anxiety in Croatian patients with multiple sclerosis, locus of control changed to more external as the disease większego znaczenia wewnętrznemu umiejscowieniu kontroli zdrowia (Ogińska-Bulik i Juczyński, 2010).

\section{POCZUCIE KONTROLI A DEPRESJA I LĘK}

Zdaniem Alberta Ellisa (2005) zaburzenia depresyjne mają destrukcyjny wpływ na jednostkę, ponieważ wywołują lęk, niepewność, poczucie winy, bierność i katastroficzne nastawienie do przyszłych zdarzeń. Ellis (2005) twierdzi, że jednym z nieracjonalnych przekonań jest przeświadczenie, iż szczęście i nieszczęście człowieka zależy od innych ludzi i od otoczenia.

Cairns i wsp. (1990) wskazali, że istnieje wyraźny trend w kierunku zmniejszenia zewnętrznego poczucia kontroli wśród uczniów szkół średnich. Także Chubb i wsp. (1997) w swoich badaniach podłużnych zaobserwowali, iż poczucie kontroli u dzieci staje się wraz z wiekiem bardziej wewnętrzne. Nie stwierdzono znaczących różnic w zakresie poczucia kontroli ze względu na płeć. Jak piszą Fiszer i Sobów (2013), powyższy stan rzeczy wynika $\mathrm{z}$ faktu, że nastolatkowe pozostają zależni od innych - nauczycieli, rodziców i w rezultacie nie mają poczucia pełnej kontroli nad tym, co ich spotyka. Ci sami autorzy podają, iż płeć okazała się czynnikiem istotnie różnicującym wyniki uzyskiwane przez studentów uniwersytetu medycznego między 20. a 25. rokiem życia: mężczyźni istotnie częściej deklarowali kontrolę wewnętrzną, kobiety natomiast uzyskały wyższe wyniki w zakresie zewnętrznego umiejscowienia kontroli zdrowia. Nie wykazano związku między płcią a poziomem depresyjności. Fiszer i Sobów podkreślają za to istotną korelację między depresyjnością a wewnętrznym umiejscowieniem kontroli zdrowia w grupie studentów. W badaniach Dudka (2014) płeć była czynnikiem istotnie różnicującym wyniki w skali Becka, a problem depresyjności w większym stopniu dotyczył dziewcząt niż chłopców.

Gomez (1998) zaznacza, iż wśród osób o zewnętrznym poczuciu kontroli diagnozuje się więcej przypadków depresji. Spotoń-Wydra (2018) w swoich badaniach nad 45 uczniami z klas piątych szkoły podstawowej w województwie zachodniopomorskim wykazała związek między umiejscowieniem kontroli a nasileniem symptomów depresyjnych: dzieci zewnątrzsterowne doświadczały zaburzeń depresyjnych częściej aniżeli wewnątrzsterowne. Także Khumalo i Plattner (2019) w badaniach na studentach w Botswanie udowodnili, że adolescenci wykazujący wewnętrzne umiejscowienie kontroli są mniej narażeni na depresję. Jak podkreślają badacze, umiejscowienie kontroli to jedna ze zmiennych, które odgrywają w depresji znaczącą rolę.

W klasycznych badaniach Hoehn-Saric i McLeod (1985) wykazali na próbie klinicznej, że pacjenci z zewnętrznym umiejscowieniem kontroli byli bardziej przygnębieni, mieli wyższy poziom lęku jako stanu, wykazywali większe niezdecydowanie i zmęczenie oraz prezentowali silniejsze objawy agorafobii niż pacjenci z wewnętrznym umiejscowieniem kontroli. Dilmaç i wsp. (2009) przeprowadzili badania w grupie studentów w wieku 17-26 lat i potwierdzili 
between external locus of control and depression and anxiety as a state (Vuger-Kovačić et al., 2007).

The COVID-19 pandemic created extraordinary, unprecedented circumstances in the lives of young people. In the present study, we intended to assess the severity of mood disturbances and anxiety in adolescents during this period. We assumed that concern over one's health and the health of loved ones during a pandemic threat can be associated with depressive symptoms and increased anxiety.

The studies described in the theoretical part of this article confirm the relationship between anxiety (as a state and as a trait) and depression and locus of control (LOC). It is therefore justified to assume that there is an association between depression and severity of anxiety and health locus of control (HLC). The analysis of such relationships during the COVID-19 pandemic in the current study represents an important contribution into the knowledge on the subject.

\section{MATERIALS AND METHODS}

\section{Research tools}

\section{State-Trait Anxiety Inventory (STAI)}

State-Trait Anxiety Inventory is designed to investigate anxiety understood as a temporary and situation-related state of an individual and anxiety as a relatively stable personality trait. One of the subscales is used to measure state anxiety $(\mathrm{X}-1)$, and the other to measure trait anxiety (X-2). Questions regarding the two scales are placed on both sides of the questionnaire sheet. Every subscale includes 20 items. For each of them, the subject is supposed select one of four categorised answers. The inventory is designed for adolescents aged 15 or more and adult individuals. Similar to the original tool, the Polish version of STAI is characterised by satisfactory psychometric properties.

\section{Kutcher Adolescent Depression Scale (KADS)}

The Kutcher Adolescent Depression Scale is composed of 6 statements. The subject rates the frequency of the state described by each statement ( 0 - hardly ever, 1 - much of the time, 2 - most of the time, 3 - all of the time). The total score is within the range of 0 to 18 . A score of 6-18 means a severe depressive disorder. The scale is intended for individuals aged 12-22 years and is characterised by high reliability (Mojs et al., 2015).

\section{Multidimensional Health Locus of Control (MHLC)}

In the present study, version A of the MHLC developed by Wallston, Wallston and DeVellis (1978; as reported by: Juczyński, 2001) and adapted to the Polish conditions by Juczyński (2001) was used. It is a standardised and normalised tool composed of 18 statements assessed on a sixpoint scale. The statements refer to convictions regarding generalised expectations in 3 dimensions of health locus of control: control located in the subject (internal), control located in other people, particularly medical personnel (powerful others) and dependency on chance and external dodatnią korelację między zewnętrznym umiejscowieniem kontroli a poziomem lęku. Song i Li (2019) stwierdzili, że umiejscowienie kontroli i nietolerancja niepewności u osób starszych są silnie powiązane z lękiem jako cechą. Analiza mediacji wykazała, iż nietolerancja niepewności częściowo pośredniczyła we wpływie umiejscowienia kontroli na lęk jako cechę. Z kolei w badaniach nad umiejscowieniem kontroli, depresją i lękiem u chorwackich pacjentów ze stwardnieniem rozsianym umiejscowienie kontroli w miarę postępu choroby zmieniało się na bardziej zewnętrzne. Jednocześnie wyniki wskazały na istnienie związku między zewnętrznym umiejscowieniem kontroli a depresją i lękiem jako stanem (Vuger-Kovačić et al., 2007).

Pandemia COVID-19 stworzyła szczególne okoliczności, bezprecedensowe w życiu młodych ludzi. W badaniach własnych chciałyśmy ocenić nasilenie występowania zaburzeń nastroju i lęku wśród młodzieży w tym okresie. Założyłyśmy, że doświadczanie obaw o zdrowie własne i bliskich w sytuacji zagrożenia pandemicznego może mieć związek z objawami depresji i nasileniem lęku.

Badania opisane w części teoretycznej niniejszego artykułu potwierdzają zależność między lękiem (jako stanem i jako cechą) oraz depresją a umiejscowieniem kontroli (LOC). Zasadne jest zatem założenie o istnieniu związku depresji i nasilenia lęku z poczuciem umiejscowienia kontroli zdrowia (HLC). Analiza wskazanych zależności podczas pandemii COVID-19 stanowi istotny wkład prezentowanego badania $\mathrm{w}$ wiedzę $\mathrm{z}$ tego zakresu.

\section{MATERIA I METODA}

\section{Narzędzia badawcze}

\section{Inwentarz Stanu i Cechy Lęku (State-Trait Anxiety Inventory, STAI)}

Jest to narzędzie przeznaczone do badania lęku rozumianego jako przejściowy i uwarunkowany sytuacyjnie stan jednostki oraz lęku rozumianego jako względnie stała cecha osobowości. Jedna $\mathrm{z}$ podskal służy do pomiaru lęku-stanu (X-1), a druga - lęku-cechy (X-2). Pytania składające się na obie skale umieszczone są po obu stronach jednego arkusza testowego. Każda podskala obejmuje 20 pozycji, na które badany odpowiada, wybierając jedną z czterech skategoryzowanych odpowiedzi. Inwentarz przeznaczony jest do badania młodzieży w wieku od 15 lat i osób dorosłych. Polska wersja STAI, podobnie jak oryginalne narzędzie, cechuje się satysfakcjonującymi właściwościami psychometrycznymi.

2. Skala Depresji Kutchera dla Młodzieży (Kutcher Adolescent Depression Scale, KADS)

Skala składa się z 6 stwierdzeń, a badany określa natężenie stanu opisywanego w każdym stwierdzeniu (0 - rzadko, 1 - dość często, 2 - przez większość czasu, 3 - cały czas). Łączna punktacja mieści się w przedziale od 0 do 18. Wynik 6-18 punktów oznacza poważne zaburzenie depresyjne. Skala przeznaczona jest dla osób w wieku 12-22 lat i charakteryzuje się wysoką rzetelnością (Mojs et al., 2015). 
factors (chance). The normalisation sample for MHLC included individuals from 18 years of age onwards (Juczyński, 2001).

\section{Characteristics of the study group}

The current study included 296 pupils from secondary schools in Wrocław, Poland: 78 boys (26\%) and 218 girls (74\%). The study was conducted in the second half of August 2020 via electronic means. A link to the study questionnaire was sent to teachers from 3 secondary schools in Wrocław who cooperate with the authors of the study. Subsequently, 6 teachers sent a request for participation to 11 classes: 6 majoring in humanities, 3 in biology and chemistry and 2 in mathematics and information technology. A link to the questionnaire was sent to 314 pupils aged 17-19 years (this age group was selected based on the research tools used). The completion of the questionnaire was voluntary. There were 18 unfilled questionnaires (5.6\%). The individuals who decided to complete the questionnaire provided their written consent to participation in the study. The mean age of the respondents was 18.1 years (standard deviation, $S D=0.64$ ). The pupils were aged 17 (53 individuals, $17.9 \%), 18$ (174 individuals, 58.8\%) and 19 years (69 individuals, 23.3\%).

\section{RESULTS}

Ten people underwent quarantine during the pandemic. No person was diagnosed with COVID-19, but 28 respondents thought they might have had the disease. In addition, no member of the participants' families were diagnosed with COVID-19; however, 23 pupils thought that there could have been an infection in the family. A serious concern over one's own health was reported by 65 subjects; a serious

\section{Wielowymiarowa Skala Umiejscowienia Kontroli Zdrowia (MHLC)}

W badaniu wykorzystano MHLC autorstwa Wallstona, Wallston i DeVellisa (1978; za: Juczyński, 2001) w polskiej adaptacji Juczyńskiego (2001) w wersji A. Jest to narzędzie wystandaryzowane i znormalizowane, złożone z 18 stwierdzeń ocenianych na sześciostopniowej skali. Stwierdzenia odnoszą się do przekonań dotyczących uogólnionych oczekiwań w 3 wymiarach umiejscowienia kontroli własnego zdrowia: kontroli umiejscowionej w podmiocie (wymiar wewnętrzny - W), kontroli umiejscowionej w osobach trzecich, w szczególności w personelu medycznym (wymiar wpływu innych - I), oraz zależności od przypadku i czynników zewnętrznych (wymiar przypadku - P). Próba normalizacyjna dla MHLC obejmuje osoby od 18. roku życia (Juczyński, 2001).

\section{Opis grupy badanej}

W badaniu wzięło udział 296 uczniów wrocławskich liceów: 78 chłopców (26\%) i 218 dziewcząt (74\%). Badanie przeprowadzono w drugiej połowie sierpnia 2020 roku, w wersji elektronicznej. Link do kwestionariusza został przesłany nauczycielom 3 wrocławskich liceów, którzy współpracują $\mathrm{z}$ autorkami badań. Następnie 6 nauczycieli rozesłało prośbę o uczestnictwo w badaniu do 11 klas: 6 o profilu humanistycznym, 3 o profilu biologiczno-chemicznym i 2 o profilu matematyczno-informatycznym. Link do ankiety otrzymało 314 uczniów w wieku 17-19 lat (grupę wiekową wybrano ze względu na zastosowane narzędzia badawcze). Wypełnienie ankiety miało charakter dobrowolny. Nie wypełniło jej 18 uczniów (5,6\%). Osoby, które podjęły się wypełnienia ankiety, wyraziły pisemną zgodę na udział w badaniu. Średni wiek respondentów wynosił 18,1 roku (odchylenie standardowe, standard deviation, $S D=0,64$ ). Struktura

\begin{tabular}{|c|c|c|c|c|c|}
\hline & $\begin{array}{c}\text { MHLC - internal } \\
\text { MHLC - wewnętrzne }\end{array}$ & $\begin{array}{c}\text { MHLC - others } \\
\text { MHLC - inni }\end{array}$ & $\begin{array}{c}\text { MHLC - chance } \\
\text { MHLC - przypadek }\end{array}$ & STAI & KADS \\
\hline$N$ & 296 & 296 & 296 & 296 & 296 \\
\hline $\begin{array}{l}\text { Mean } \\
\text { Średnia }\end{array}$ & 24.8 & 20.3 & 20.1 & 48.4 & 7.38 \\
\hline $\begin{array}{l}\text { Median } \\
\text { Mediana }\end{array}$ & 25.0 & 20.0 & 20.0 & 48.5 & 8.00 \\
\hline $\begin{array}{l}\text { Standard deviation } \\
\text { Odchylenie standardowe }\end{array}$ & 4.50 & 4.79 & 5.15 & 10.8 & 3.18 \\
\hline $\begin{array}{l}\text { Variance } \\
\text { Wariancja }\end{array}$ & 20.2 & 22.9 & 26.6 & 117 & 10.1 \\
\hline $\begin{array}{l}\text { Minimum } \\
\text { Minimum }\end{array}$ & 7 & 7 & 8 & 27 & 0 \\
\hline $\begin{array}{l}\text { Maximum } \\
\text { Maksimum }\end{array}$ & 34 & 34 & 34 & 73 & 13 \\
\hline $\begin{array}{l}\text { Skewness } \\
\text { Skośność }\end{array}$ & -0.373 & 0.133 & 0.0817 & -0.0582 & -0.379 \\
\hline $\begin{array}{l}\text { Kurtosis } \\
\text { Kurtoza }\end{array}$ & 0.276 & 0.0391 & -0.113 & -1.04 & -0.426 \\
\hline
\end{tabular}

Tab. 1. Descriptive statistics of the variables

Tab. 1. Statystyki opisowe zmiennych 


\begin{tabular}{|c|c|c|c|c|c|c|c|c|c|}
\hline & \multicolumn{9}{|c|}{$\begin{array}{c}\text { Gender } \\
\text { Pteć }\end{array}$} \\
\hline & \multicolumn{3}{|c|}{$\begin{array}{c}\text { Girls } \\
\text { Dziewczęta }\end{array}$} & \multicolumn{3}{|c|}{$\begin{array}{l}\text { Boys } \\
\text { Chłopcy }\end{array}$} & \multirow[b]{2}{*}{$\begin{array}{l}\text { U-statistic } \\
\text { StatystykaU U }\end{array}$} & \multirow[b]{2}{*}{$p$} & \multirow[b]{2}{*}{$\begin{array}{l}\text { Effect } \\
\text { Efekt }\end{array}$} \\
\hline & $n$ & $M$ & SD & $n$ & $M$ & SD & & & \\
\hline STAI & 218 & 50.25 & 10.44 & 78 & 43.41 & 10.28 & 5,450 & $<0.001$ & 0.359 \\
\hline \multirow[t]{4}{*}{ KADS } & 218 & 7.76 & 2.97 & 78 & 6.29 & 3.50 & 6,459 & 0.002 & 0.240 \\
\hline & \multicolumn{9}{|c|}{$\begin{array}{l}\text { Concern over the health of family members } \\
\text { Obawy ozdrowie członków rodziny }\end{array}$} \\
\hline & \multicolumn{3}{|c|}{$\begin{array}{c}\text { None } \\
\text { Brak }\end{array}$} & \multicolumn{3}{|c|}{$\begin{array}{c}\text { Present } \\
\text { Obecne }\end{array}$} & & & \\
\hline & $n$ & M & SD & $n$ & M & SD & $\begin{array}{l}\text { U-statistic } \\
\text { Statystyka U }\end{array}$ & $p$ & $\begin{array}{l}\text { Effect } \\
\text { Efekt }\end{array}$ \\
\hline STAI & 204 & 48.02 & 10.59 & 92 & 49.40 & 11.30 & 8,677 & 0.299 & 0.075 \\
\hline KADS & 204 & 7.11 & 3.00 & 92 & 7.96 & 3.50 & 7,805 & 0.020 & 0.168 \\
\hline
\end{tabular}

Tab. 2. Anxiety and depression level and gender and concern over the health of family members: mean differences measured with the MannWhitney $\mathrm{U}$ test

Tab. 2. Poziom lęku i depresji a płeć i obawy o zdrowie członków rodziny - średnie różnice mierzone testem U Manna-Whitneya

concern over the health of family members was indicated by 92 subjects.

In a multiple choice question, the pupils were to select the restrictions introduced by the Polish government on 15 March which they found the most difficult. The most frequently chosen option was prohibition on leaving home (130 participants - 44\%) and lack of possibility to meet friends ( 99 subjects $-33 \%$ considered this to be the most upsetting). Other restrictions indicated as difficult by the participants included the obligation to wear a face mask (46 individuals $-16 \%$ ), closed clubs and discos $(31-11.5 \%)$, school closure $(23-7.8 \%)$, the need to clean and disinfect hands frequently $(22-7.4 \%)$, being unable to spend time at shopping centres $(8-2.7 \%)$, lack of possibility to go to fitness clubs, gyms and swimming pools $(5-1.6 \%)$ and a ban on cinema, theatre and concerts $(1-0.03 \%)$.

Descriptive statistics of the variables: locus of control, anxiety and depression can be found in Tab. 1.

A KADS score higher than 6 indicates a diagnosis of a depressive disorder. In the study sample, 222 individuals (75\%) met the criteria for depression: 175 girls $(80.2 \%)$ and 47 (60.2\%) boys.

In a normalisation study (Tysarczyk, 1976; as reported by: Sosnowski et al., 2011), the level of anxiety as a state was $39.84(S D=9.26)$ on average in a group of girls aged $16-17$ years, and $43.42(S D=7.88)$ in a group of girls aged 18-19 years. Among boys aged 16-17 years the level of anxiety as a state was $36.07(S D=7.68)$ on average, and among boys aged $18-19$ years it was $38.91(S D=8.49)$. In the current study, the mean level of anxiety as a state was 50.25 in girls and 41.50 in boys. Although normalisation data coming from the 1970s should be treated with caution, we believe that the level of anxiety both among boys and girls can be considered to be elevated at the time of the present study. wieku obejmowała uczniów w wieku 17 (53 osoby, 17,9\%), 18 (174 osoby, $58,8 \%$ ) i 19 lat (69 osób, 23,3\%).

\section{WYNIKI}

Dziesięć osób zostało w trakcie pandemii poddanych kwarantannie. U nikogo nie zdiagnozowano COVID-19, ale 28 respondentów nie było pewnych, czy nie chorowało. Ponadto u żadnego z członków rodziny uczestników nie stwierdzono COVID-19, jednak 23 uczniów nie miało pewności, czy w rodzinie nie było infekcji. Sześćdziesięciu pięciu badanych zgłosiło poważne obawy o własne zdrowie, a 92 - poważne obawy o zdrowie członków rodziny.

$\mathrm{W}$ pytaniu wielokrotnego wyboru uczniowie zaznaczali, które z ograniczeń wprowadzonych 15 marca 2020 roku przez polski rząd były dla nich najtrudniejsze. Najczęściej wskazywano na zakaz wychodzenia z domu (130 uczestników - 44\%) i niemożność spotkania się z przyjaciółmi (99 uczestników - 33\% uznało to za najbardziej denerwujące). Inne ograniczenia zgłaszane jako trudne to nakaz noszenia maseczek (46 osób - 16\%), zamykanie klubów i dyskotek (31 - 11,5\%), zamykanie szkół ( 23 - 7,8\%), konieczność częstego czyszczenia i dezynfekcji rąk (22 $7,4 \%)$, niemożność spędzania czasu w galeriach handlowych $(8-2,7 \%)$, brak możliwości korzystania z klubów fitness, siłowni i basenów $(5-1,6 \%)$ oraz zakaz chodzenia do kina, teatru i na koncerty $(1-0,03 \%)$.

Statystyki opisowe zmiennych: poczucie umiejscowienia kontroli, lęk, depresja znajdują się w tab. 1.

Wyniki KADS wyższe niż 6 wskazują na diagnozę zaburzenia depresyjnego. W badanej próbie 222 osoby (75\%) spełniały kryteria depresji - było to $175(80,2 \%)$ dziewcząt i 47 $(60,2 \%)$ chłopców.

W badaniach normalizacyjnych (Tysarczyk, 1976, za: Sosnowski et al., 2011) poziom lęku jako stanu w grupie dziewcząt w wieku 16-17 lat wynosił średnio 39,84 $(S D=9,26)$, 


\begin{tabular}{|c|c|c|c|c|c|c|c|}
\hline & $M$ & SD & 1 & 2 & 3 & 4 & 5 \\
\hline $\begin{array}{l}\text { 1. MHLC - internal } \\
\text { 1. MHLC - wewnętrzne }\end{array}$ & 24.8 & 4.50 & - & & & & \\
\hline $\begin{array}{l}\text { 2. MHLC - others } \\
\text { 2. MHLC - inni }\end{array}$ & 20.3 & 4.79 & $0.159^{* *}$ & - & & & \\
\hline $\begin{array}{l}\text { 3. MHLC - chance } \\
\text { 3. MHLC - przypadek }\end{array}$ & 20.1 & 5.15 & $-0.165^{* * *}$ & -0.040 & - & & \\
\hline 4. STAI & 48.4 & 10.80 & $-0.246^{* * *}$ & -0.003 & $0.272^{* * *}$ & - & \\
\hline 5. KADS & 7.38 & 3.18 & $-0.235^{* * *}$ & -0.054 & $0.230^{* * *}$ & $0.730^{* * *}$ & - \\
\hline $\begin{array}{l}\text { Cronbach's a } \\
\text { a Cronbacha }\end{array}$ & & & 0.58 & 0.60 & 0.53 & 0.90 & 0.67 \\
\hline
\end{tabular}

Tab. 3. Pearson correlation coefficients and descriptive indicators of health locus of control and severity of depression and anxiety Tab. 3. Współczynniki korelacji Pearsona i wskaźniki opisowe umiejscowienia kontroli zdrowia oraz nasilenia depresji i lęku

Mean differences were calculated between groups divided according to gender and variables associated with COVID-19 (undergoing quarantine, experiencing the disease oneself or by a family member, fear of becoming infected or concern that family members might contract the disease) in terms of the severity of depressive symptoms and anxiety as a state. Due to the condition of equality of variance not being met, the Mann-Whitney $U$-test was applied. Analysis revealed that only gender and fear of family members becoming infected had an effect on the level of anxiety and depression (Tab. 2). The severity of anxiety as a state and of depressive symptoms was significantly higher among adolescent girls than boys. In addition, individuals who reported anxious thoughts about the possibility of a family member contracting COVID-19 had a significantly higher level of depressive symptoms than those who did not express similar concerns. However, gender influenced the severity of symptoms associated with mental health to a much greater extent than concern over the health of loved ones, which is reflected in the effect size.

Since skewness and kurtosis values were below the critical levels for all variables ( $<1$ for skewness and $<2$ for kurtosis; George and Mallery, 2010), the parametric Pearson's test was used to analyse the correlation between anxiety as a state, depression and health locus of control. The associations between these variables turned out to be significant. Internal health locus of control correlated negatively with both anxiety as a state $(r=-0.25, p<0.001)$ and depression $(r=-0.23, p<0.001)$. Chance external health locus of control correlated positively with depression $(r=0.23, p<0.001)$ and anxiety $(r=0.27, p<0.001)$. Powerful others external health locus of control did not display any statistically significant relationship with depression or anxiety. It is not surprising that there was also a high correlation between depression and anxiety as a state $(r=0.73, p<0.001)$.

According to the results obtained in this study (Tab. 3), adolescents who believe that they control their health themselves are less susceptible to symptoms of anxiety and depression. However, the conviction that random external factors determine one's health has a significant relationship a w grupie dziewcząt w wieku 18-19 lat - 43,42 $(S D=7,88)$. Wśród chłopców w wieku 16-17 lat było to średnio 36,07 $(S D=7,68)$, a w próbie chłopców w wieku 18-19 lat $38,91(S D=8,49)$. W badaniach własnych średni poziom lęku jako stanu to 50,25 u dziewcząt i 41,50 u chłopców. Choć dane normalizacyjne, pochodzące $\mathrm{z}$ lat 70. XX wieku, należy traktować ostrożnie, sądzimy, że poziom lęku zarówno wśród chłopców, jak i wśród dziewcząt w czasie prowadzenia badań własnych można uznać za podwyższony. Obliczono średnie różnice w zakresie nasilenia objawów depresji i lęku jako stanu między grupami podzielonymi ze względu na płeć oraz ze względu na zmienne związane z COVID-19 (odbycie kwarantanny, przeżycie choroby osobiście lub przez członka rodziny, obawy o własne zakażenie i o zachorowanie członków rodziny). Z uwagi na odstępstwo założenia o równości wariancji zmiennych użyto testu $U$ Manna-Whitneya. Analizy wykazały, że jedynie płeć i strach przed zakażeniem u członków rodziny różnicowały poziom lęku i depresji (tab. 2). Nasilenie lęku jako stanu i objawów depresyjnych było istotnie większe wśród dorastających dziewcząt niż wśród chłopców. Ponadto osoby, które zgłosiły niepokojące myśli o możliwości zarażenia się COVID-19 przez kogoś z rodziny, doświadczały znacznie wyższego poziomu objawów depresyjnych niż osoby, które nie zgłosiły podobnych obaw. Jednakże płeć różnicowała nasilenie objawów związanych ze zdrowiem psychicznym zdecydowanie bardziej niż lęk o zdrowie bliskich - na co wskazuje siła efektu.

Ponieważ wartości skośności i kurtozy dla wszystkich zmiennych były poniżej wartości krytycznych $(<1$ dla skośności i <2 dla kurtozy; George i Mallery, 2010), analizę korelacji między lękiem jako stanem, depresją a umiejscowieniem kontroli zdrowia przeprowadzono za pomocą parametrycznego testu Pearsona. Związki między wymienionymi zmiennymi okazały się istotne. Wewnętrzne umiejscowienie kontroli zdrowia korelowało ujemnie zarówno $\mathrm{z}$ lękiem-stanem $(r=-0,25, p<0,001)$, jak i z depresją $(r=-0,23, p<0,001)$. Zewnętrzne umiejscowienie kontroli zdrowia związane z przypadkiem korelowało dodatnio $\mathrm{z}$ depresją $(r=0,23, p<0,001)$ i lękiem $(r=0,27$, $p<0,001)$. Zewnętrzne umiejscowienie kontroli zdrowia 


\section{DISCUSSION}

According to the results of the present study, the prevalence of depressive symptoms among adolescents during the COVID-19 pandemic is between $60.2 \%$ and $80.2 \%$ depending on gender. Symptoms of depression and anxiety were both more common and stronger in girls than in boys. As many as $75 \%$ of the $17-19$-year-old pupils reported decreased mood, sense of hopelessness, decreased energy levels, increased fatigability, loss of interests, anhedonia, tension, irritation or suicidal thoughts, which indicates serious affective disorders. One can assume that factors associated with the pandemic: isolation, concern over one's health and that of family members, lack of social meetings and other factors are conducive to depression among adolescents. However, since the questionnaires were completed by volunteers, any generalisation of the results to the whole population of Polish adolescents should be made with caution. The results of the present study are much higher than the ones from previous research, particularly regarding depression (Bansal et al., 2009; Brent and Pan, 2011; Dymowska and Nowicka-Sauer, 2015; Modrzejewska and Bomba, 2010; Weber et al., 2018), but also anxiety (Bansal et al., 2009, Weber et al., 2018). However, they are consistent with the results of research conducted during the COVID-19 pandemic, which demonstrated a high prevalence of depression (43\%) and anxiety (37\%) (Zhou et al., 2020). The rate of symptoms for both depression and anxiety was significantly higher in girls than in boys.

The high rates of anxiety and depression observed in the present study may indicate a gradual increase in difficulties experienced as part of the pandemic. A study by Czeisler et al. (2020) conducted in the USA on a sample of 5,470 young adults in the second half of June 2020 indicates that $40.9 \%$ of the respondents experienced symptoms of a mental disorder. In a study carried out in Bangladesh also in June (Islam et al., 2020a), as many as $82.4 \%$ of the participants had mild symptoms of depression. The results of further published studies provide information on the prevalence of depression and anxiety symptoms at various stages of the pandemic. Perhaps the time when the present study was conducted had a specific effect on the mental health of adolescents. The end of summer holidays, the upcoming school year in a new, uncertain reality, the perspective of the return of remote learning and social isolation could have been mood-deteriorating and anxiety-increasing factors. In addition, an increase in the incidence of COVID-19 was observed in Poland at the time. The study did not include any questions regarding chronic diseases in the subjects or their family members or any traumatic situations unrelated to COVID-19 that could affect the level of anxiety and depression. Such information could have been relevant for the interpretation of the results.

In addition, the subjects of the study are not a representative sample for Poland due to a substantial disproportion between the number of girls and boys. This may have been due to the predominant educational profile of the pupils: the majority of them związane $z$ wpływem innych nie wykazało istotnego statystycznie związku ani z depresją, ani z lękiem. Nie jest zaskakujące, że wystąpiła także wysoka korelacja między depresją a lękiem jako stanem $(r=0,73, p<0,001)$.

Jak wskazują uzyskane wyniki (tab. 3), nastolatkowie przekonani o tym, iż sami kontrolują swoje zdrowie, są mniej podatni na doświadczanie objawów lęku i depresji. Przekonanie, że o zdrowiu decydują przypadkowe czynniki zewnętrzne, wykazuje natomiast istotny związek $\mathrm{z}$ objawami lęku i depresji.

\section{OMÓWIENIE}

Zgodnie z wynikami badań własnych rozpowszechnienie objawów depresji wśród młodzieży wynosi w dobie pandemii COVID-19 między 60,2\% a 80,2\%, w zależności od płci. Symptomy depresji i lęku były zarówno częstsze, jak i silniejsze u dziewcząt niż u chłopców. Aż 75\% przebadanych uczniów w wieku 17-19 lat zgłaszało obniżony nastrój, poczucie beznadziejności, zmniejszoną energię, zwiększoną męczliwość, utratę zainteresowań, anhedonię, uczucie napięcia, irytacji czy myśli samobójcze, co wskazuje na poważne zaburzenia afektywne. Można zakładać, że czynniki związane z pandemią - alienacja, lęk o zdrowie własne i rodziny, brak spotkań towarzyskich i inne - sprzyjają depresji wśród młodzieży. Ponieważ jednak ankietę wypełniali ochotnicy, należy zachować ostrożność przy generalizowaniu wyników na całą populację polskiej młodzieży.

Wyniki uzyskane w badaniach własnych są znacznie wyższe od wyników wcześniejszych badań - zwłaszcza w odniesieniu do depresji (Bansal et al., 2009; Brent i Pan, 2011; Dymowska i Nowicka-Sauer, 2015; Modrzejewska i Bomba, 2010; Weber et al., 2018), ale także lęku (Bansal et al., 2009, Weber et al., 2018). Są natomiast spójne z rezultatami badań przeprowadzonych w okresie pandemii COVID-19, w których wykazano wysokie rozpowszechnienie objawów depresji (43\%) i lęku (37\%) (Zhou et al., 2020). U dziewcząt wskaźnik objawów obu zaburzeń był istotnie wyższy niż wśród chłopców.

Uzyskane w prezentowanym badaniu wysokie wskaźniki lęku i depresji mogą oznaczać stopniowy przyrost doświadczanych trudności w miarę trwania pandemii. Badania Czeislera i wsp. (2020) przeprowadzone w USA na próbie 5470 młodych dorosłych w drugiej połowie czerwca 2020 roku wskazują, że 40,9\% respondentów doświadczało symptomów zaburzenia psychicznego. W badaniach zorganizowanych również w czerwcu w Bangladeszu (Islam et al., 2020a) aż 82,4\% uczestników miało łagodne symptomy depresji. Wyniki kolejnych publikowanych badań dostarczają informacji na temat rozpowszechnienia symptomów depresji i lęku na różnych etapach pandemii. Być może czas, w którym przeprowadzono omawiane tu badania własne, w specyficzny sposób oddziaływał na zdrowie psychiczne adolescentów. Koniec wakacji, zbliżający się rok szkolny w nowej, niepewnej rzeczywistości, wizja powrotu do nauczania zdalnego i społecznej izolacji mogły stanowić 
majored in the humanities. Not all of the questionnaires sent were completed. Perhaps boys were the majority of the group of individuals who decided not to complete the questionnaire. Another important factor affecting the percentage values of the prevalence of anxiety disorders and depression is the sensitivity of the research tool. In the present study, the distinction between mild and severe course of depression was not used; only the cut-off criterion for KADS was used. Therefore, it can be assumed that $60.2-80.2 \%$ of the subjects experience mild to severe depression. When interpreting the results, one also needs to take into account the fact that not all individuals who meet the KADS criterion for depression require psychological or psychiatric care. However, the results do indicate that after 6 months of the pandemic an alarmingly low mood and anxiety can be observed in Polish adolescents. The mental condition of young people should therefore be monitored and conclusions should be drawn regarding the possible rate of changes in psychopathology as the pandemic continues, and preventative measures should be taken.

It is worth emphasising that factors associated with COVID-19 (fear of family members contracting the disease) have a significant impact on the severity of depressive symptoms. Anxiety over one's family's health turned out to increase depressive states. In addition, a significant correlation between the severity of anxiety and that of depression was confirmed: the higher the score for anxiety, the higher the severity of depression. The most unpleasant restrictions for young people during the pandemic included prohibition on leaving home (130 participants - 44\%) and lack of possibility to meet one's friends (99 participants - 33\%). It is possible that it was mandatory social isolation and restricted contacts with peers that triggered deterioration in the adolescents' mental state and increased their anxiety. At a young age, autonomy and peer relations, which are significantly impeded in a pandemic, are an important part of identity formation.

In the current study, internal health locus of control correlated negatively with both depression and anxiety. However, chance external health locus of control correlated positively with depression and anxiety. These results are consistent with the results of studies performed before the COVID-19 outbreak, which indicated the presence of an association between external locus of control and depressive disorders in children and adolescents (Fiszer and Sobów, 2013; Gomez, 1998; Khumalo and Plattner, 2019; McCauley et al., 1988; Spotoń-Wydra, 2018) and between a high level of anxiety and external locus of control (Dilmaç et al., 2009). During the COVID-19 pandemic, the young people who took part in research experienced a high level of anxiety and depression, with the severity of the symptoms depending on health locus of control. Adolescents who believe that the control over their health lies with themselves are less susceptible to the symptoms of anxiety and depression.

The degree to which a given person believes to have control czynniki obniżające nastrój i nasilające lęk. Dodatkowo w Polsce obserwowano wówczas wzrost liczby zachorowań na COVID-19. W badaniu nie uwzględniono pytań o choroby przewlekłe występujące u uczestników lub członków rodziny ani o sytuacje traumatyczne niezwiązane z COVID-19, mogące wpływać na poziom lęku i depresyjności. Taka informacja mogłaby się okazać znacząca dla interpretacji uzyskanych wyników.

Ponadto osoby objęte badaniem nie są próbą reprezentatywną dla Polski ze względu na wyraźną dysproporcję między dziewczętami a chłopcami. Może ona wynikać z dominującego profilu edukacyjnego - większość uczestników to uczniowie klas o profilu humanistycznym. Nie wszystkie rozesłane ankiety zostały wypełnione. Być może w grupie osób, które nie zdecydowały się wypełnić ankiety, dominowali chłopcy.

Innym istotnym czynnikiem wpływającym na procentowe wartości rozpowszechnienia zaburzeń lękowych i depresji jest czułość narzędzia badawczego. W prezentowanym badaniu nie zastosowano podziału na łagodny i ciężki przebieg depresji, a jedynie kryterium odcięcia obowiązujące w przypadku KADS. Można zatem uznać, że 60,2-80,2\% badanych doświadcza depresji w nasileniu od łagodnego do ciężkiego. Interpretacja uzyskanego wyniku wymaga też uwzględnienia faktu, że nie wszystkie osoby spełniające kryterium depresji w KADS wymagają opieki psychologicznej albo psychiatrycznej. Jest to jednak wynik, który wskazuje, że po 6 miesiącach pandemii obserwujemy u polskiej młodzieży niepokojąco obniżony nastrój i lęk. Należy więc monitorować stan psychiczny i wyciągać wnioski na temat ewentualnej dynamiki zmian w zakresie psychopatologii w miarę trwania pandemii, a także podejmować działania prewencyjne.

Warto podkreślić, że czynniki związane z COVID-19 obawy o zachorowanie członków rodziny - mają duże znaczenie dla nasilenia objawów depresyjnych. Lęk o zdrowie rodziny okazał się elementem nasilającym stany depresyjne. Dodatkowo potwierdzona została istotna korelacja między nasileniem lęku a nasileniem depresji: im wyższy wskaźnik lęku, tym wyższe nasilenie stanów depresyjnych. Najdotkliwszymi ograniczeniami w okresie pandemii były dla młodzieży zakaz wychodzenia z domu (130 uczestników - 44\%) i niemożność spotkania się z przyjaciółmi (99 uczestników - 33\%). Niewykluczone, że to właśnie przymusowa alienacja społeczna i ograniczenie kontaktu $\mathrm{z}$ rówieśnikami zainicjowały pogarszanie się stanu psychicznego nastolatków i wzmogły lęk. W wieku rozwojowym autonomia i relacje rówieśnicze, znacząco utrudnione w sytuacji pandemii, są istotnymi elementami tworzenia tożsamości.

W badaniach własnych wewnętrzne umiejscowienie kontroli zdrowia korelowało ujemnie zarówno z depresją, jak i z lękiem. Natomiast zewnętrzne umiejscowienie kontroli zdrowia związane z przypadkiem korelowało dodatnio $\mathrm{z}$ depresją i lękiem. Wyniki te są spójne $\mathrm{z}$ rezultatami badań prowadzonych przed wybuchem pandemii COVID-19, 
difficult circumstances and determines the choice of a coping strategy. Individuals with a strong internal locus of control probably interpret the COVID-19 pandemic circumstances as possible to control, place a greater emphasis on their own effort and believe that they have the ability to influence their future. As a result, they may be more willing to search for reliable information on the threat or use social support. They may also be more resistant to extreme circumstances and enjoy better mental health, which has a beneficial impact on the quality of life.

However, a belief that health is determined by random external factors significantly correlates with the symptoms of anxiety and depression. Young people who believe that their health depends on chance have a particularly difficult experience with the pandemic. Contrary media reports regarding, for example, efficacy of preventative measures or the rate of survival of the virus in the air, and the increasing presence of conspiracy theories (Islam et al., 2020b) can lead to stronger relationships described above. However, the lack of correlation between the severity of anxiety and depressive symptoms and powerful others locus of control may indicate that adolescents who believe that their health depends on their environment (parents, doctors) feel sufficiently safe during the pandemic.

\section{CONCLUSION}

The results of the current study confirm that internal health locus of control is definitely more beneficial for mental health, which has some important practical implications. On the one hand, it is important to support internal sense of control in young people as part of preventative action. Developing a sense of influence over their health and life in adolescents, i.e. creating a sense of efficacy, can protect them against the consequences of difficult situations that are harmful to mental health. On the other hand, restrictions associated with the pandemic should be introduced in a thoroughly considered manner, respecting the subjectivity of the individuals affected by them. Sudden school closure, uncertainty regarding the date of their opening, banning young people from leaving home on their own and reducing their contact with peers undoubtedly had an impact on their sense of safety and autonomy. In the future, it is worth considering creating a space for young people for self-determination and codeciding on substantial life changes. This could take the form of an information campaign that would emphasise the personal impact of young people on the course of the pandemic depending on how well they abide by the restrictions.

Longitudinal research would be beneficial for the understanding of the effect of the pandemic on the severity of depression and anxiety. It is also worth conducting a replication study on a group with a similar number of girls and boys. The present study can be treated as a source of hypothesis that social isolation and limited self-determination are important risk factors for episodes of depression and anxiety in adolescents. wskazujących na istnienie związku między zewnętrznym umiejscowieniem kontroli a występowaniem zaburzeń depresyjnych u dzieci i młodzieży (Fiszer i Sobów, 2013; Gomez, 1998; Khumalo i Plattner, 2019; McCauley et al., 1988; Spotoń-Wydra, 2018) oraz między wysokim poziomem lęku a zewnętrznym poczuciem kontroli (Dilmaç et al., 2009).

W okresie pandemii COVID-19 przebadana młodzież doświadczała wysokiego poziomu lęku i depresji, a nasilenie objawów było zależne od poczucia kontroli zdrowia. Adolescenci, których charakteryzuje przekonanie, iż kontrola nad ich zdrowiem zależy od nich samych, są mniej podatni na doświadczanie symptomów lęku i depresji.

To, w jakim stopniu dana osoba wierzy, że ma kontrolę nad sytuacją, znacząco wpływa na adaptację do trudnych okoliczności i determinuje wybór strategii radzenia sobie. Osoby o silnym wewnętrznym umiejscowieniu kontroli zdrowia prawdopodobnie interpretują okoliczności pandemii COVID-19 jako możliwe do kontrolowania, kładą większy nacisk na własny wysiłek i są przekonane, że mają zdolność wpływania na swoją przyszłość. W rezultacie mogą chętniej poszukiwać wiarygodnych informacji na temat zagrożenia lub korzystać ze wsparcia społecznego. Mogą też być bardziej odporne na ekstremalne okoliczności i cieszyć się lepszym zdrowiem psychicznym, co korzystnie wpływa na jakość życia.

Z kolei przekonanie, że o stanie zdrowia decydują czynniki zewnętrzne związane z przypadkiem, istotnie koreluje z objawami lęku i depresji. Młodzi ludzie, którzy uważają, że ich zdrowie zależy od przypadku, szczególnie dotkliwie przeżywają pandemię. Sprzeczne doniesienia medialne, choćby na temat skuteczności środków prewencyjnych czy przeżywalności wirusa w powietrzu, i coraz większa powszechność teorii spiskowych (Islam et al., 2020b) mogą prowadzić do nasilenia opisanych wyżej zależności. Natomiast brak korelacji między nasileniem lęku i objawami depresji a umiejscowieniem kontroli związanym $\mathrm{z}$ wpływem innych może wskazywać na to, że adolescenci, którzy uważają, że ich zdrowie zależy od otoczenia - rodziców, lekarzy w trakcie pandemii czują się wystarczająco bezpiecznie.

\section{PODSUMOWANIE}

Wyniki badań własnych potwierdzają, że wewnętrzne umiejscowienie kontroli zdrowia jest zdecydowanie korzystniejsze dla zdrowia psychicznego, co niesie za sobą ważne implikacje praktyczne. $Z$ jednej strony istotne jest wzmacnianie wewnętrznego poczucia kontroli u młodych ludzi w ramach działań prewencyjnych. Budowanie w adolescentach przekonania, że mają wpływ na swoje zdrowie i życie, czyli kreowanie poczucia skuteczności, może chronić przed niekorzystnymi dla zdrowia psychicznego następstwami sytuacji trudnych. Z drugiej strony ograniczenia funkcjonowania związane z pandemią powinny być wprowadzane w sposób przemyślany i z poszanowaniem podmiotowości osób, których dotyczą. Nagłe zamknięcie szkół, niepewność co do terminu ich ponownego otwarcia, 


\section{Conflict of interest}

The authors do not report any financial or personal affiliations to persons or organisations that could adversely affect the content of or claim to have rights to this publication.

\section{References / Piśmiennictwo}

Argyle M: Psychologia stosunków międzyludzkich. Wydawnictwo Naukowe PWN, Warszawa 2002.

Bansal V, Goyal S, Srivastava K: Study of prevalence of depression in adolescent students of a public school. Ind Psychiatry J 2009; 18: 43-46.

Bomba J, Orwid M: Zaburzenia zdrowia psychicznego w okresie młodzieńczym. Postępowanie, profilaktyka, błędy w postępowaniu. In: Rybakowa M (ed.): Medycyna wieku młodzieńczego. Zaburzenia i choroby nabyte, metody prewencji. Vol. 2, Wydawnictwo Medyczne, Kraków 2004: 54-56.

Brent DA, Pan L: Zaburzenia depresyjne u dzieci i młodzieży. In: Ebert MH, Nurcombe B, Loosen PT et al. (eds.): Psychiatria. Vol. 1, Wydawnictwo Czelej Spółka z o.o., Lublin 2011: 265-270.

Cairns E, McWhirter L, Duffy U et al.: The stability of self-concept in late adolescence: gender and situational effects. Pers Individ Dif 1990; 11: 937-944.

Cattell RB: Anxiety and motivation: theory and crucial experiments. In: Spielberger CD (ed.): Anxiety and Behavior. Academic Press, New York 1966: 23-62.

Chen F, Zheng D, Liu J et al.: Depression and anxiety among adolescents during COVID-19: a cross-sectional study. Brain Behav Immun 2020; 88: 36-38.

Chubb NH, Fertman CI, Ross JL: Adolescent self-esteem and locus of control: a longitudinal study of gender and age differences. Adolescence 1997; 32: 113-129.

Czeisler MÉ, Lane RI, Petrosky E et al.: Mental health, substance use, and suicidal ideation during the COVID-19 pandemic - United States, June 24-30, 2020. MMWR Morb Mortal Wkly Rep 2020; 69: 1049-1057.

Dilmaç B, Hamarta E, Arslan C: Analysing the trait anxiety and locus of control of undergraduates in terms of attachment styles. Educational Sciences: Theory and Practice 2009; 9: 143-159.

Douglas PK, Douglas DB, Harrigan DC et al.: Preparing for pandemic influenza and its aftermath: mental health issues considered. Int J Emerg Ment Health 2009; 11: 137-144.

Dudek M: Depresja wśród młodzieży licealnej. Rocznik Komisji Nauk Pedagogicznych 2014; 67: 139-151.

Dymowska A, Nowicka-Sauer K: Depresja wśród młodzieży - problem wciąż aktualny. Forum Med Rodz 2015; 9: 124-126.

Ellis A: Feeling Better, Getting Better, Staying Better: Profound SelfHelp Therapy for Your Emotions. Impact Publishers, Atascadero 2005.

Fiszer K, Sobów T: Związek umiejscowienia kontroli zdrowia z depresyjnością wśród studentów uczelni medycznej. Med Og Nauk Zdr 2013; 19: 294-299.

Flack WF, Laird JD (eds.): Emotions in Psychopathology: Theory and Research. Oxford University Press, New York 1998.

George D, Mallery P: SPSS for Windows Step by Step: A Simple Guide and Reference, 17.0 Update. 10th ed., Allyn \& Bacon, Boston 2010.

Ghosh R, Dubey MJ, Chatterjee S et al.: Impact of COVID-19 on children: special focus on the psychosocial aspect. Minerva Pediatr 2020; 72: 226-235.

Gomez R: Locus of control and avoidant coping: direct, interactional and mediational effects on maladjustment in adolescents. Pers Individ Dif 1998; 24: 325-334.

Guessoum SB, Lachal J, Radjack R et al.: Adolescent psychiatric disorders during the COVID-19 pandemic and lockdown. Psychiatry Res 2020; 291: 113264.

Helmer SM, Krämer A, Mikolajczyk RT: Health-related locus of control and health behaviour among university students in North Rhine Westphalia, Germany. BMC Res Notes 2012; 5: 703. pozbawienie młodych ludzi możliwości samodzielnego wychodzenia $\mathrm{z}$ domu i ograniczenie kontaktów $\mathrm{z}$ rówieśnikami bez wątpienia rzutowały na poziom zaspokojenia potrzeb bezpieczeństwa i autonomii. W przyszłości warto wziąć pod uwagę stworzenie młodzieży przestrzeni do samostanowienia i współdecydowania o dużych życiowych zmianach. Mogłoby to przybrać formę kampanii informacyjnych podkreślających osobisty wpływ młodych ludzi na przebieg pandemii w przypadku przestrzegania/nieprzestrzegania obostrzeń.

Korzystne dla zrozumienia wpływu sytuacji pandemii na nasilenie depresji i lęku byłoby przeprowadzenie badań longitudinalnych. Warto również dokonać replikacji badań na grupie, w której liczba dziewcząt i chłopców byłaby zbliżona. Prezentowane tu badania można potraktować jako źródło hipotezy, że alienacja społeczna i ograniczenie możliwości samostanowienia to ważne czynniki ryzyka epizodów depresyjnych i lękowych u adolescentów.

\section{Konflikt interesów}

Autorki nie zgłaszaja żadnych finansowych ani osobistych powiązań $z$ innymi osobami lub organizacjami, które mogłyby negatywnie wplynać na treść publikacji oraz rościć sobie prawo do tej publikacji.

Hoehn-Saric R, McLeod DR: Locus of control in chronic anxiety disorders. Acta Psychiatr Scand 1985; 72: 529-535.

International Federation of Red Cross and Red Crescent Societies: Mental Health and Psychosocial Support for Staff, Volunteers and Communities in an Outbreak of Novel Coronavirus. International Federation of Red Cross and Red Crescent Societies, Hong Kong 2020.

Islam MA, Barna SD, Raihan $\mathrm{H}$ et al.: Depression and anxiety among university students during the COVID-19 pandemic in Bangladesh: a web-based cross-sectional survey. PLoS One 2020a; 15: e0238162.

Islam MS, Sarkar T, Khan SH et al.: COVID-19-related infodemic and its impact on public health: a global social media analysis. Am J Trop Med Hyg 2020b; 103: 1621-1629.

Jarema M, Dudek D, Czernikiewicz A: Dysfunkcje poznawcze w depresji - niedoszacowany objaw czy nowy wymiar? Psychiatr Pol 2014; 48: 1105-1116.

Juczyński Z: Narzędzia pomiaru w promocji i psychologii zdrowia. Pracownia Testów Psychologicznych Polskiego Towarzystwa Psychologicznego, Warszawa 2001.

Juczyński Z: Narzędzia pomiaru w psychologii zdrowia. Przegląd Psychologiczny 1999; 42: 43-56.

Khumalo T, Plattner IE: The relationship between locus of control and depression: a cross-sectional survey with university students in Botswana. S Afr J Psychiatr 2019; 25: 1221.

Kołodziejek M: Depresja u dzieci i młodzieży: podstawy teoretyczne, psychoterapia poznawczo-behawioralna. Psychoterapia 2008; 2 (145): 15-33.

McCauley E, Mitchell JR, Burke P et al.: Cognitive attributes of depression in children and adolescents. J Consult Clin Psychol 1988; 56: 903-908.

Modrzejewska R, Bomba J: Rozpowszechnienie zaburzeń psychicznych i używania substancji psychoaktywnych w populacji 17-letniej młodzieży wielkomiejskiej. Psychiatr Pol 2010; 44: 579-592.

Mojs E, Bartkowska W, Kaczmarek ŁD et al.: Właściwości psychometryczne polskiej wersji skróconej Skali Depresji Kutchera dla Młodzieży (Kutcher Adolescent Depression Scale) - pomiar depresji w grupie studentów. Psychiatr Pol 2015; 49: 135-144.

Ogińska-Bulik N, Juczyński Z: Osobowość: stres a zdrowie. Difin, Warszawa 2010. 
Pużyński S, Wciórka J: Klasyfikacja zaburzeń psychicznych i zaburzeń zachowania w ICD-10. Opisy kliniczne i wskazówki diagnostyczne. Uniwersyteckie Wydawnictwo Medyczne Vesalius, Kraków 2007.

Rybakowski J, Pużyński S, Wciórka J: Psychiatria. Vol. 2, Psychiatria kliniczna. Elsevier Urban \& Partner, Wrocław 2010

Sęk H: Kierunki behawioralne i podejście poznawcze w psychologii klinicznej. In: Sęk H (ed.): Psychologia kliniczna. Wydawnictwo Naukowe PWN, Warszawa 2005: 106-118.

Song Y, Li B: Locus of control and trait anxiety in aged adults: the mediating effect of intolerance of uncertainty. Int J Ment Health Addict 2019; 17: 13-21.

Sosnowski T, Wrześniewski K, Jaworowska A et al.: STAI - Inwentarz Stanu i Cechy Lęku. Polska adaptacja STAI. Pracownia Testów Psychologicznych Polskiego Towarzystwa Psychologicznego, Warszawa 2011.

Spotoń-Wydra M: Wybrane zasoby osobiste a nasilenie symptomów depresyjnych u dzieci - badanie pilotażowe. Med Rodz 2018; 21: 322-327.

Trzęsowska-Greszta E, Sikora R, Kopeć WM: Typ relacji w rodzinie a ryzyko depresji w fazie dorastania - w ujęciu teorii systemowej rodzin. Kwartalnik Naukowy Fides et Ratio 2014; 19: 186-204.
Vuger-Kovačić D, Gregurek R, Kovačić D et al.: Relation between anxiety, depression and locus of control of patients with multiple sclerosis. Mult Scler 2007; 13: 1065-1067.

Wallston KA: The importance of placing measures of health locus of control beliefs in a theoretical context. Health Educ Res 1991; 6: 251-252.

Wallston KA, Wallston BS: Who is responsible for your health? The construct of health locus of control. In: Sanders GS, Suls J (eds.): Social Psychology of Health and Illness. Lawrence Erlbaum, Hillsdale, NJ 1982: 65-95.

Weber S, Puta C, Lesinski M et al.: Symptoms of anxiety and depression in young athletes using the Hospital Anxiety and Depression Scale. Front Physiol 2018; 9: 182.

Xie X, Xue Q, Zhou Y et al.: Mental health status among children in home confinement during the coronavirus disease 2019 outbreak in Hubei province, China. JAMA Pediatr 2020; 174: 898-900.

Zhou SJ, Zhang LG, Wang LL et al.: Prevalence and socio-demographic correlates of psychological health problems in Chinese adolescents during the outbreak of COVID-19. Eur Child Adolesc Psychiatry 2020; 29: 749-758. 